\title{
Development of Interactive Learning Media with Adobe Animate CC in Basic Programming Learning at SMK Negeri 1 Kabanjahe
}

\author{
Horasman Simanihuruk ${ }^{1}$, Mukhtar $^{2}$, Samsidar Tanjung $^{3}$ \\ \{manru31@gmail.com ${ }^{1}$ \} \\ Universitas Negeri Medan Postgraduate Education ${ }^{1,2,3}$
}

\begin{abstract}
This study aims to: (1) Develop interactive learning media with Adobe Animate CC applications in Basic Programming Subjects, (2) Know the feasibility of using Interactive learning media with Adobe Animate CC applications in Basic Programming Subjects, (3) Know the effectiveness of media use Interactive learning with the Adobe Animate CC application on Basic Programming Subjects. This research is a Research and Development (R\&D) research with research procedures using the ADDIE model. Development of interactive learning media, consisting of 5 stages, namely: (1) Analysis: Conducting needs analysis), (2) Design: Determine the performance achieved and the selection of appropriate test methods, (3) Develop: Generate and validate learning resources, (4) Implement: Preparing the Learning Environment and Including Students, (5) Evaluate: Make final improvements according to the advice and processing of data obtained. Determination of the feasibility level of interactive learning media based on the validation test of experts and trials to students and continued with the effectiveness test. Overall, based on the assessment of material experts and media construction experts as well as the results of student trials and effectiveness tests, it can be concluded that interactive learning media with Adobe Animate $\mathrm{CC}$ on learning is appropriate and more effective in improving student learning outcomes.
\end{abstract}

Keywords: Interactive Learning Media, Basic Programming, Development.

\section{Introduction}

Education plays a major role in the process of developing human resources. Improving the quality of education is a process that cannot be separated from the process of improving the quality of human resources themselves. Education is the main key to the success of a nation in competing at the global level. The importance of education is a process of transferring information and existing values. During this process, there will be a change in reasoning and attitude towards better things.

National education objectives contained in Law no. 20 of 2003 is developing the potential of students to become human beings who believe and devote to God Almighty; noble, healthy, knowledgeable, capable, creative, independent and be a democratic and responsible citizen. The 2013 curriculum sets out the specific objectives of vocational schools, including: (1) Producing graduates who have competencies that are in accordance with the demands of the business world and industry both nationally and globally. (2) Producing graduates who have vocational skills in technical expertise programs that meet the competencies and certifications required by the 
world of work and professional technical associations that are relevant and able to compete in the global market. (3) Producing a variety of innovative research products and programs in PTK (Vocational Technology Education) disciplines and engineering disciplines that are useful for improving the quality of human resources in national development. (4) Being a center of information and dissemination of technology and vocational education and engineering (5) Producing educators / trainers in the field of vocational technology that has an entrepreneurial spirit (entrepreneurship).

As teachers, we must have good quality learning in order to become professional teachers. The maximum learning process can be seen from the process of learning activeness and student learning outcomes so that what is the goal of improving the quality of learning and educational goals in Indonesia can be implemented optimally. Learning outcomes that can be mastered by students according to Bloom include three aspects, namely cognitive aspects, affective aspects and psychomotor aspects.

Learning facilities and resources are naturally developed by schools in accordance with what is outlined in the National Education Standards, ranging from procurement, maintenance and improvement. This is based on the fact that schools are the most aware of the needs of learning facilities and resources, both adequacy, suitability, and the latest, especially learning resources designed (by design) by teachers for the benefit of learning.

The teacher has a strategic position towards the success of student learning. In learning, it is not uncommon to find teachers dominating learning by applying old teaching methods, even done from year to year without innovation. Old teaching methods tend to be applied with lecture methods with monotonous learning media so that they can inhibit interactivity, absorptive capacity, and student interest in subject matter. The old learning system at school is believed to be a system that is no longer effective. In this case the creativity of the Basic Programming teacher in managing learning has a very big influence in improving student learning outcomes.

In the process of implementing Basic Programming learning, the teacher must make preparations with full consideration because the success of the implementation of a learning major lies with the teacher. Besides being useful as a control tool, teaching preparation is also useful as a guide for the teacher himself. One of the preparations that must be prepared carefully by the teacher is learning media. Learning media are all things that can be used by educators as a means to facilitate learning.

The media component in the learning process is a communication process that takes place in a system. Therefore, learning media occupies an important position as one of the components of the learning system. One important element in learning components and planning is determining the learning media that will be used in the learning process. It is intended that the understanding of the material and concepts can be clearly understood by students.

The accuracy of choosing learning media will greatly affect students' understanding of the basic competencies being studied by students. According to Ampera (2016), if learning media is chosen properly and correctly, it can overcome obstacles that occur in the learning process. The use of appropriate learning media can influence the achievement of learning objectives. This will improve the quality of learning, especially learning achievement Basic Programming. Media is a learning tool that can be used to facilitate ongoing learning activities. The media can be interpreted as an intermediary that connects teachers and students. The media is used to help and support the creation of effective, efficient and interesting learning processes. 


\section{Method}

The method used in this research is research and development with ADDIE development design. The subject in this study was the material "Implementing the use of data types, variables, constants, operators and expressions" contained in the 2018 Multimedia revised syllabus. While the object in this study was SMK Negeri 1 Kabanjahe students who were studying basic competencies "Applying the use of types data, variables, constants, operators and expressions ". Data obtained by giving questionnaires and objective tests of learning outcomes. The data obtained were then tested for normality and homogeneity. The hypothesis of this study will be tested using t-test analysis.

\section{Results}

The data obtained from this study are the results of the assessment by material experts and instructional media experts and student learning outcomes of SMK Negeri 1 Kabanjahe. Based on the results of the assessment of learning material experts assess that learning media with adobe animate cc with subject matter applying the use of data types, variables, constants, operators and expressions have had eligibility on three aspects of assessment which include aspects of guidance and information with a mean score of 3.75 with a reasonable interpretation , aspects of multimedia content / material with a mean score of 3.42 with a decent interpretation and an evaluation aspect with a mean score of 3.63 with a decent interpretation. This shows that interactive learning media developed can meet the demands of learning needs. The mean score of the assessment of material experts on learning media with adobe animate $\mathrm{cc}$ in learning "Applying the use of data types, variables, constants, operators and expressions" is shown in Table 1.

Table 1. The mean score of the assessment of material experts on learning media with adobe animate cc

\begin{tabular}{lcl}
\hline Aspect of assessment & Mean score & Interpretation \\
\hline Guidelines and Information 3.75 Eligible & 3.75 & feasible \\
Multimedia content / material & 3.42 & feasible \\
evaluation & 3.63 & feasible \\
\hline Total & 3.6 & feasible \\
\hline
\end{tabular}

Furthermore, the data results of the assessment on interactive learning media using Adobe Animate $\mathrm{CC}$ as shown in table 2.

Table 2. Mean scores of Interactive Learning Media Assessment Results with adobe animate cc by media experts.

\begin{tabular}{lcc} 
Aspect of assessment & Mean score & Interpretation \\
\hline Guidelines and Information & 4.33 & Very feasible
\end{tabular}




\begin{tabular}{lcl} 
Multimedia operations & 3.7 & feasible \\
Systematics, Aesthetics and Principles of Media Design & 4.04 & feasible \\
\hline Total & 4.02 & Feasible \\
\hline
\end{tabular}

Furthermore, the results of the questionnaire from students about the level of student acceptance of interactive learning media with adobe animate $\mathrm{cc}$ in individual trials are shown in table 3 .

Table 3. Mean scores of Interactive Learning Media Assessment Results with adobe animate cc in individual trials.

\begin{tabular}{lcc}
\hline Aspect of assessment & Mean score & Interpretation \\
\hline Guidelines and Information & 3.75 & High Acceptance \\
Media material & 4.06 & High Acceptance \\
Evaluation & 3.87 & High Acceptance \\
Media facility design & 3.82 & High Acceptance \\
Pedagodic effect & 4.16 & High Acceptance \\
\hline \multicolumn{1}{c}{ Total } & 3.93 & High Acceptance \\
\hline
\end{tabular}

Furthermore, the data obtained in this study are student learning outcomes with interactive learning media with adobe animate cc on basic competencies applying data types, variables, constants, operators and expressions. Based on the results of the study it can be seen that the minimum, maximum, average and standard deviation learning outcomes in the media development group at SMK Negeri 1 Kabanjahe can be seen in Table 4.

Table 4. Minimum Learning Outcomes, Maximum, Mean and Standard Deviation of students in the Intervention Group (experimental class) at SMK Negeri 1 Kabanjahe.

\begin{tabular}{lcccc}
\hline Learning Outcomes & Min. & Max. & Mean & Std. Deviation \\
\hline Pre Media Development & 3 & 12 & 8.09 & 2.786 \\
Post Media Development & 10 & 26 & 19.65 & 4.762 \\
& & & & \\
\hline
\end{tabular}

Table 5. Data Normality Test for Experiment Class and Control Class

\begin{tabular}{lccc}
\hline \multicolumn{1}{c}{ Data } & Class & $\boldsymbol{l}$-count & $\boldsymbol{l}$-table \\
\hline Pretest & Experiment & 0.1383 & 0.1566 \\
Posttest & Experiment & 0.1396 & 0.1566 \\
Pretest & Control & 0.1276 & 0.1498 \\
Posttest & Control & 0.1463 & 0.1498 \\
\hline
\end{tabular}

Based on the results of normality testing in the experimental class and the control class in Table 4, it is known that the pretest and posttest data in both classes produce 1-count values $\leq 1$ tables. Thus, it can be concluded that the learning outcomes data in the experimental class and the control class are normally distributed. Normality test conducted in this study uses the Lilifors test. 
Table 6. Test Homogeneity of Pretest and Posttest Data

\begin{tabular}{lccc}
\hline Data & Class & p-value & A \\
\hline \multirow{2}{*}{ Pretest } & $\begin{array}{c}\text { experiment } \\
\text { control }\end{array}$ & 1,28 & 1,79 \\
& $\begin{array}{c}\text { experiment } \\
\text { Posttest }\end{array}$ & 1,46 & 1,79 \\
& control & & \\
\hline
\end{tabular}

Based on the results of homogeneity testing in the experimental and control classes in Table 5, the results of the pretest calculations from the experimental and control classes obtained f-count 1.28 and the posttest of the experimental and control classes obtained 1.46.According to the test criterion, if f-count $\leq$ f-table means homogeneous data. Thus, it can be concluded that the pretest and posttest learning outcome data in the experimental class and the control class are homogeneous.

\section{Discussion}

\subsection{Discussion of Product Development Results}

Development of interactive learning media with adobe animate cc based on the stages as stated in the procedure. The results of further development are carried out due diligence or validation by experts who have been determined. Based on the results of the validation done, the product in the form of an interactive learning cd was declared eligible to be continued in the field trials. The learning media developed have met the standards based on the design standards of instructional media development and learning material standards.

The product development research carried out is directed to produce products in the form of interactive learning media with adobe animate cc with basic competencies applying data types, variables, constants, operators and expressions in SMK Negeri 1 Kabanjahe which are used to improve student learning outcomes. The aspects were revised and refined based on data analysis and tested and input from material experts, instructional media experts. It aims to explore some aspects that are common in the process of developing a product.

The results of the assessment presented by the material experts about the development of interactive learning media with adobe animate cc gave an average mean score of 3.89 so that the learning media were included in the "proper" interpretation so that they could be accepted and suitable for use in the learning process. Learning media experts on interactive learning media with Adobe Animate CC gave an average mean score of 4.02 so that the development of instructional media with adobe animate cc was included in the "Decent" interpretation. Meanwhile, from the results of individual trials the mean score was 3.93 with the interpretation of "high acceptance". From the discussion above it can be concluded that the development of interactive learning media with adobe animate cc on basic competencies "applying data types, variables, constants, operators and expressions" is suitable for use as a learning medium in SMK Negeri 1 Kabanjahe.

\subsection{Discussion on Research Results of Product Effectiveness Test}


Based on statistical tests that have been done, the results of hypothesis test analysis are obtained, namely $\mathrm{t}$-count $=3.678$ and $\mathrm{t}$-table $=2,000$ which is $\mathrm{t}$-count $>\mathrm{t}$-table, this means the use of interactive learning media with adobe animate cc can improve student learning outcomes in basic competencies " applying data types, variables, constants, operators and expressions "at SMK Negeri 1 Kabanjahe with an influence on improving learning outcomes by $41.17 \%$.

Interactive Learning Media with adobe animate cc can improve student learning outcomes at SMK Negeri 1 Kabanjahe. This research was related to improving the quality of design in a digital format, with specific targets to produce multimedia-based animation as a learning medium and an effective learning resource for learning fashion design [1]. Using multimediabased interactive animation, effective to improve the mastery of concepts and skills to make fashion designs in digital format, and relevance with another research $[5,6]$.

Interactive Multimedia based on Adobe Flash CS6 in the pattern making lesson is approved by media experts and material experts, each of whom communicates with two validators [2]. Media experts rated interactive multimedia in very good ratings with a percentage $(86.67 \%)$, and experts in interactive multimedia assessment materials with a percentage of $89.5 \%$. In the small group trials obtained $63 \%$, the moderate group trials gained $74.49 \%$, and the large group trials gained $90.54 \%$ with very agreed criteria which meant that interactive multimedia based on Adobe Flash CS6 was suitable for use in learning activities.

\section{Conclusions}

Based on the results of research that has been done and the results of data analysis obtained can be concluded as follows. Based on statistical tests that have been done, the results of hypothesis test analysis are obtained, namely t-count $=3.678$ and $\mathrm{t}$-table $=2,000$ which is $\mathrm{t}$ count> t-table, this means the use of interactive learning media with adobe animate cc can improve student learning outcomes the basic competencies apply data types, variables, constants, operators and expressions in SMK Negeri 1 Kabanjahe, with an influence on improving learning outcomes by $41.17 \%$.

The results showed that the development of interactive learning media with adobe animate cc had a positive effect in creating an active and enjoyable learning process. The development of interactive learning media with adobe animate cc has proven to make students more enthusiastic and responsible for learning more actively, which in turn has an impact on student learning outcomes better than without using media. Therefore, the development of interactive learning media can be recommended for use in vocational student learning processes. Suggestions that can be given to teachers, so that they can implement interactive learning media with adobe animate cc by planning better learning, so that the results obtained are more optimal and efficient.

\section{References}

[1] Wianna. Interactive Multimedia-Based Animation: A Study of Effectiveness on Fashion Design Technology Learning. Journal of Physics: Conference Series (2018). 
[2] Ampera. Multimedia Interaktif berbasis Adobe Flash CS6 pada mata pelajaran pembuatan pola. Journal (2016).

[3] Fathurrohman. Muhammad. Belajar dan Pembelajaran Modern, Konsep Dasar, Inovasi dan Teori Pembelajaran.Yogyakarta: Garudhawaca (2017).

[4] Sugiyono. Metode Penelitian Pendidikan Pendekatan Kuantitatif, Kualitatif, dan R\&D. Bandung: Alfabeta (2018).

[5] Sriadhi, et al. The Effect of Tutorial Multimedia on the Transformator Learning Outcomes Based on the Students' Visual Ability. IOP Conf. Series: Materials Science and Engineering 384 (2018) 012059 doi:10.1088/1757-899X/384/1/012059.

[6] Sriadhi, H.Sitompul, Restu. Development of web-virtual laboratory to improve the effectiveness and efficiency of remedial learning. Journal of Physics: Conference Series 1402 (2019) 077059 IOP Publishing doi:10.1088/1742-6596/1402/7/077059 